\title{
Neuroendocrine Modulation of the Immune Response after Trauma and Sepsis: Does It Influence Outcome?
}

\author{
Philipp Kobbe ${ }^{1}$, Felix M. Bläsius ${ }^{1}$ (1) , Philipp Lichte $^{1}{ }^{1}$, Reiner Oberbeck ${ }^{2}$ and \\ Frank Hildebrand ${ }^{1, *}$ \\ 1 Deparment of Trauma and Reconstructive Surgery, University Hospital RWTH Aachen, D-52074 Aachen, \\ Germany; p.kobbe@ukaachen.de (P.K.); fblaesius@ukaachen.de (F.M.B.); plichte@ukaachen.de (P.L.) \\ 2 Deparment of Trauma and Hand Surgery, Wald-Klinikum, 07548 Gera, Germany; \\ reiner.oberbeck@wkg.srh.de \\ * Correspondence: fhildebrand@ukaachen.de; Tel.: +49-241-89350
}

Received: 19 June 2020; Accepted: 16 July 2020; Published: 18 July 2020

\begin{abstract}
Although the treatment of multiple-injured patients has been improved during the last decades, sepsis and multiple organ failure (MOF) still remain the major cause of death. Following trauma, profound alterations of a large number of physiological systems can be observed that may potentially contribute to the development of sepsis and MOF. This includes alterations of the neuroendocrine and the immune system. A large number of studies focused on posttraumatic changes of the immune system, but the cause of posttraumatic immune disturbance remains to be established. However, an increasing number of data indicate that the bidirectional interaction between the neuroendocrine and the immune system may be an important mechanism involved in the development of sepsis and MOF. The aim of this article is to highlight the current knowledge of the neuroendocrine modulation of the immune system during trauma and sepsis.
\end{abstract}

Keywords: trauma; sepsis; DHEA; steroids; catecholamine

\section{Introduction}

Despite profound improvements in the initial care and in the treatment of multiple injured patients that follows, MOF and sepsis represent an ongoing threat [1,2]. It is assumed that the posttraumatic changes of the immune system crucially contribute to the development of these complications in multiple-injured patients. This includes pro- and anti-inflammatory changes of the immune system while an excessive reaction of both of the components leads to a massive disturbance of the immunological homeostasis [2-4].

Parallel to the changes of the immune system in multiple-injured as well as in septic patients, neuroendocrine systems are activated. Activation of the sympatho-adrenergic system (SAS) leads to a massively increased release of the catecholamines adrenaline and noradrenaline into the circulation $[5,6]$. The released adrenaline mainly originates from the adrenal medulla, and the noradrenaline mainly originates from the postganglionic sympathetic nerve fibers [6]. An increased release of catecholamines occurs in the initial stage as well as in the acute and late stage of sepsis and is enhanced by the released pro-inflammatory cytokines (Interleukin (IL)-6, Tumor Necrosis Factor (TNF)- $\alpha$ ) [6]. Furthermore, the spleen, the lung and the gut-associated lymphoid tissue (GALT) are tightly sympathetically innervated and play a crucial role with respect to the adrenergic modulation of the immune system. In addition, it could be demonstrated that most of the cells of the immune system are equipped with $\alpha$ - as well as $\beta$-adrenergic receptors on their cell surface and that many of these cells are able to synthesize catecholamines themselves [7]. 
Apart from the activation of the SAS, a massive release of hormones of the hypothalamicpituitary-adrenal axis (HPA-axis) or the hypothalamic-gonadal axis (HPG-axis) is found $[5,6]$. Activation of the HPA-axis is detectable after severe traumata as well as in septic patients and is responsible for a massive increase of cortisol and its release hormone ACTH. Here, the stimulation of the HPA-axis by pro-inflammatory cytokines like TNF- $\alpha$, IL-1 and IL-6 plays a crucial role [8]. Between the amount of the cortisol level and the severity of the illness, a positive correlation exists. In cases of a prolonged course of disease, a peripheral glucocorticoid resistance develops characterized by normal or decreased ACTH and elevated cortisol levels [6].

With regard to the HPG-axis, which is likewise controlled by the release of hormones of the hypothalamus, decreased testosterone levels could be found in men after severe trauma and during sepsis whereas women react with an increase of their estrogen levels, presumably based on an increased aromatizing of androgens. In this case, it also comes to an influence of pro-inflammatory cytokines on hormone release [9].

Blood levels of the steroid hormone Dehydroepiandrosterone (DHEA) and its sulphated pattern (DHEA-S) are significantly decreased in critically ill and septic patients $[10,11]$. DHEA is the quantitatively most important human steroid hormone, which is produced mostly in the adrenal gland but also in the gonads. DHEA has not only a potent immunomodulatory activity by itself, but it is also considered to be a precursor of the androgen and estrogen biosynthesis [12]. During sepsis and trauma, a dissociation of cortisol and DHEA is found, which leads to an imbalance between immune-suppressive and immune-stimulating steroid hormones $[8,13]$. In accordance with this, it was shown that depressed levels of circulating DHEA in patients with sepsis are positively correlated to the risk of death $[14,15]$.

Until now, it was assumed that the activation of neuroendocrine systems (SAS, HPA-axis, HPG-axis, DHEA) during trauma and sepsis serves the adaption of physiological systems like metabolism, heart/circulation, tissue regeneration and the central nervous system onto the elevated requirements.

The aim of this review is, on the one hand, to highlight current insights on how neuroendocrine released messengers are responsible for immunomodulation following severe trauma and during sepsis and, on the other hand, to find out whether this knowledge has been transferred into clinical practice.

\section{Hypothalamic-Pituitary-Adrenal (HPA) Axis}

Trauma and sepsis cause complex alterations of the hypothalamic-pituitary-adrenal axis and glucocorticoid signaling [16]. The immunomodulatory effects of glucocorticoids are well described. On the one hand, glucocorticoids inhibit the release of pro-inflammatory cytokines from Thelper-1 (Th1) and antigen-presenting cells (APCs), and on the other hand, glucocorticoids induce the release of anti-inflammatory cytokines from T helper-2 (Th2) cells [17]. Through thismechanism glucocorticoids cause a Th1/Th2-shift of the immunological response. Additionally, glucocorticoids inhibit the function of neutrophil and eosinophil granulocytes as well as macrophages [18,19]. Glucocorticoid-induced immune suppression is used in autoimmune disorders and after organ transplant, and theoretically, these immunomodulatory effects may attenuate the overwhelming inflammatory response following severe trauma or during sepsis. Especially under consideration that critical ill patients show signs of relative adrenal insufficiency by suppression of the HPG axis due to the critical illness as well as sedative/analgesic drugs [16,20], the systemic substitution of glucocorticoids and the modulation of the metabolism of glucocorticoids appears reasonable. Recently, the role of $11 \beta$-Hydroxysteroid dehydrogenase type $1(11 \beta-H S D 1)$ in acute and chronic inflammation has been pointed out [21-23]. $11 \beta$-HSD1 causes an intracellular conversion of inactive cortisone to the active cortisol. Therefore, $11 \beta-H S D 1$ is an intracellular gate-keeper for glucocorticoid action [22]. Interestingly, the expression of $11 \beta-H S D 1$ is greatly up-regulated during differentiation of monocytes into macrophages thus theoretically curbing the inflammatory potency of these cells [21]. However, it appears that this intracellular immunomodulation by $11 \beta-\mathrm{HSD} 1$ is disturbed during trauma and hemorrhage resulting in an inefficacy of released glucocorticoids to modulate the inflammatory response [24]. 
There are numerous animal studies in which corticosteroid administration consistently protected against lethal sepsis; however, clinical trials in sepsis found much less consistency in survival benefits from corticosteroids, although most trials demonstrated faster resolution in shock and organ dysfunction [25]. The Corticosteroid Therapy of Septic Shock (CORTICUS) study showed no benefit of hydrocortisone on survival or reversal of shock in patients with septic shock [26]. Although hydrocortisone treatment of patients in septic shock resulted in faster improvement of organ function, mainly of the cardiovascular system, this had no effect on mortality [27]. The HYPOLYTE (Hydrocortisone Polytraumatise) study showed that in intubated trauma patients hydrocortisone significantly reduced the risk of hospital-acquired pneumonia, however, again without altering the mortality rate [28]. Critics of glucocorticoid application argue that acute-phase sepsis is associated with increased glucocorticoid receptor expression and cortisol concentrations, possibly implying no need for exogenous substitution, which may even increase glucocorticoid resistance through a negative feedback mechanism [29]. Furthermore, glucocorticoid application is known to have potential hazardous side-effects, especially a slight increase of the incidence of clinically important gastrointestinal bleeding in critical ill patients [30].

Despite above mentioned findings of single studies, recent data from meta-analyses suggests with a low- to moderate-quality evidence that a long course of low-dose corticosteroids reduces 28-day mortality without inducing major complications [25,31-33]. Nonetheless, corticosteroid therapy for septic and trauma patients remains controversial despite general agreement that corticosteroids improve sepsis-associated comorbidities, such as shock, organ dysfunction, and length of hospital stay.

An immunomodulatory effect is also found for other hormones of the anterior pituitary gland as $\mathrm{ACTH}, \beta$-endorphin, and prolactin. The administration of prolactin during experimental polymicrobial sepsis in mice increased the mortality rate from $47 \%$ to $81 \%$. This effect was paralleled by a significant increase of splenocyte apoptosis rate and a marked depression of splenocyte proliferation. Furthermore, prolactin administration profoundly affected cellular cytokine release (IL-2, IL-6, IFN- $\gamma$ ) $48 \mathrm{~h}$ after induction of sepsis by cecal ligation and puncture [34]. However, the available literature about the immunomodulatory effects of pituitary hormones is controversial despite the suppressive effects on the immune cell proliferation and activity or rather the release of pro-inflammatory cytokines predominantly shown (Table 1) [35]. 
Table 1. Clinical studies.

\begin{tabular}{|c|c|c|c|c|c|}
\hline \multicolumn{6}{|c|}{ HPA Axis } \\
\hline Insult & Author & Type of Study & $\begin{array}{c}\text { Number of } \\
\text { Included Patients }\end{array}$ & Medication/Substance & Result \\
\hline Sepsis & Sprung et al. & $\begin{array}{c}\text { multicenter, randomized, } \\
\text { double-blind, placebo-controlled }\end{array}$ & 499 & Hydrocortisone & no improvement of survival \\
\hline & & & & & no improvement of reversal of shock \\
\hline Sepsis & Lian et al. & meta-analysis & 10,044 & Corticosteroids & reduction of 28-day mortality \\
\hline Sepsis & Fang et al. & meta-analysis & 9564 & Corticosteroids & reduction of 28-day mortality \\
\hline \multicolumn{6}{|c|}{ HPG Axis } \\
\hline Insult & Author & Type of Study & $\begin{array}{c}\text { Number of } \\
\text { Included Patients }\end{array}$ & Medication/Substance & Result \\
\hline Surgical patients & Bulger et al. & $\begin{array}{l}\text { randomized, double-blind, } \\
\text { placebo-controlled }\end{array}$ & 41 & Oxandrolone & prolonged $\mathrm{CMV}$, no improved outcome \\
\hline Trauma/Sepsis & Frink et al. & monocenter, comparative study & 143 & none & lower MODS and sepsis rates in females \\
\hline Trauma/Sepsis & Offner et al. & monocenter, comparative study & 545 & none & male gender is associated with infections \\
\hline Trauma/Sepsis & Trentzsch et al. & $\begin{array}{l}\text { retrospective, multicenter, } \\
\text { comparative study }\end{array}$ & 10,334 & none & $\begin{array}{l}\text { female gender is associated with } \\
\text { improved organ function and lower } \\
\text { sepsis rates }\end{array}$ \\
\hline Trauma/Sepsis & Schoeneberg et al. & $\begin{array}{l}\text { retrospective, multicenter, } \\
\text { comparative study }\end{array}$ & 962 & none & $\begin{array}{l}\text { female gender is associated with lower } \\
\text { sepsis rates }\end{array}$ \\
\hline Surcical patients & Wichmann et al. & monocenter, comparative study & 40 & none & $\begin{array}{l}\text { lower IL-6 concentrations in women } \\
\text { compared to men after surgery }\end{array}$ \\
\hline Surgical patients/Sepsis & Wichmann et al. & monocenter, comparative study & 4218 & none & lower sepsis incidence in women \\
\hline Trauma/Sepsis & Deitch et al. & monocenter, comparative study & 5192 & none & $\begin{array}{l}\text { hormonally active women had a better } \\
\text { physiological response }\end{array}$ \\
\hline
\end{tabular}


Table 1. Cont.

\begin{tabular}{|c|c|c|c|c|c|}
\hline \multicolumn{6}{|c|}{ HPG Axis } \\
\hline Insult & Author & Type of Study & $\begin{array}{c}\text { Number of } \\
\text { Included Patients }\end{array}$ & Medication/Substance & Result \\
\hline Trauma & Haider et al. & $\begin{array}{l}\text { retrospective, multicenter, } \\
\text { comparative study }\end{array}$ & 48,394 & none & $\begin{array}{l}\text { hormonally active women showed an } \\
\text { improved survival }\end{array}$ \\
\hline Trauma & Wohltmann & $\begin{array}{l}\text { retrospective, multicenter, } \\
\text { comparative study }\end{array}$ & 20,261 & none & $\begin{array}{l}\text { hormonally active womed showed an } \\
\text { improved survival }\end{array}$ \\
\hline Trauma & Oberholzer et al. & monocenter, comparative study & 1276 & none & $\begin{array}{l}\text { females showed an decreased } \\
\text { posttraumatic morbidity }\end{array}$ \\
\hline Trauma & George et al. & $\begin{array}{l}\text { retrospective, multicenter, } \\
\text { comparative study }\end{array}$ & 155,691 & none & females showed an improved survival \\
\hline Trauma/Sepsis & Rappold et al. & monocenter, comparative study & 1229 & none & $\begin{array}{l}\text { female gender offered no protection from } \\
\text { ARDS, pneumonia, sepsis or death }\end{array}$ \\
\hline Trauma & Gannon et al. & $\begin{array}{l}\text { retrospective, multicenter, } \\
\text { comparative study }\end{array}$ & 22,332 & none & $\begin{array}{l}\text { no influence of female gender on } \\
\text { outcome }\end{array}$ \\
\hline Sepsis & Eachempati et al. & $\begin{array}{l}\text { prospective, monocenter, } \\
\text { comparative study }\end{array}$ & 1348 & none & $\begin{array}{l}\text { female gender is an independent } \\
\text { predictor of increased mortality }\end{array}$ \\
\hline Trauma & Napolitano et al. & monocenter, comparative study & 18,892 & none & $\begin{array}{l}\text { no influence of female gender on } \\
\text { outcome }\end{array}$ \\
\hline Trauma & Dossett et al. & $\begin{array}{l}\text { prospective, multicenter, } \\
\text { comparative study }\end{array}$ & 991 & none & $\begin{array}{l}\text { serum estradiol levels were a marker for } \\
\text { injury severity and a predictor of death }\end{array}$ \\
\hline Sepsis & Sakr et al. & $\begin{array}{l}\text { prospective, multicenter, } \\
\text { comparative study }\end{array}$ & 3902 & none & women had a lower sepsis prevalence \\
\hline \multicolumn{6}{|c|}{ DHEA } \\
\hline Insult & Author & Type of Study & $\begin{array}{c}\text { Number of } \\
\text { Included Patients }\end{array}$ & Medication/Substance & Result \\
\hline $\begin{array}{c}\text { Influence of trauma on } \\
\text { systemic DHEA/DHEAS } \\
\text { levels }\end{array}$ & Foster et al. & $\begin{array}{l}\text { prospective, monocenter, } \\
\text { comparative study }\end{array}$ & 95 patients & DHEA/DHEAS & $\begin{array}{l}\text { 1. Rapid decrease of DHEA after } \\
\text { trauma with recovery to the } \\
\text { normal range by } 3 \text { months } \\
\text { 2. DHEAS rapidly reduced after } \\
\text { trauma with no recovery until } 6 \\
\text { months after trauma }\end{array}$ \\
\hline
\end{tabular}


Table 1. Cont

\begin{tabular}{|c|c|c|c|c|c|c|}
\hline \multicolumn{7}{|c|}{ DHEA } \\
\hline Insult & Author & Type of Study & $\begin{array}{c}\text { Number of } \\
\text { Included Patients }\end{array}$ & Medication/Substance & & Result \\
\hline $\begin{array}{l}\text { Influence of trauma on } \\
\text { systemic DHEA/DHEAS } \\
\text { levels }\end{array}$ & Brorsson et al. & $\begin{array}{l}\text { prospective, monocenter, } \\
\text { comparative study }\end{array}$ & 50 patients & DHEA/DHEAS & 1. & $\begin{array}{l}\text { Significant decrease of DHEA and } \\
\text { DHEAS over the observation } \\
\text { period of } 5 \text { days }\end{array}$ \\
\hline $\begin{array}{l}\text { Effects of sepsis and } \\
\text { trauma on DHEA/DHEAS } \\
\text { after ACTH stimulation }\end{array}$ & Arlt et al. & $\begin{array}{l}\text { prospective, monocenter, } \\
\text { comparative study }\end{array}$ & 212 patients & DHEA/DHEAS & $\begin{array}{l}1 . \\
2 . \\
3 .\end{array}$ & $\begin{array}{l}\text { Decreased DHEAS levels after } \\
\text { trauma and sepsis } \\
\text { Increased DHEA levels after sepsis, } \\
\text { decreased levels after trauma } \\
\text { No increase of DHEA after } \\
\text { ATCH-application in } \\
\text { septic patients }\end{array}$ \\
\hline \multicolumn{7}{|c|}{ SAS/PCS } \\
\hline Insult & Author & Type of Study & $\begin{array}{c}\text { Number of } \\
\text { Included Patients }\end{array}$ & Medication/Substance & & Result \\
\hline Sepsis & Macchia et al. & $\begin{array}{l}\text { retrospective, multicenter, } \\
\text { comparative study }\end{array}$ & 9465 & beta-blocker & & reduction of 28-day mortality \\
\hline Sepsis & Morelli et al. & $\begin{array}{c}\text { prospective, randomized, } \\
\text { monocenter, comparative study }\end{array}$ & 154 & beta-blocker (esmolol) & & reduction of mortality \\
\hline Trauma & Bukur et al. & $\begin{array}{l}\text { monocenter, retrospective, } \\
\text { comparative study }\end{array}$ & 663 & beta-blocker & & reduction of mortality \\
\hline
\end{tabular}




\section{Hypothalamic-Pituitary-Gonadal (HPG) Axis}

A relevant interaction between the HPG-axis and severe trauma and infections has been well described. On the one hand, traumatic and infectious insults induce a central suppression of the HPG axis with reduced gonadal androgen production and an associated state of catabolism (reduction of muscle mass, increased nitrogen loss) [36]. Therefore, the therapeutic use of a synthetic androgen (oxandrolone) has been investigated to support the switch to an anabolic situation. However, in contrast to burn injuries, it was not found to exert beneficial effects after major trauma [37]. On the other hand, sex hormones have the potential to significantly influence the posttraumatic course [11]. The so-called gender-dependent dimorphism of morbidity and mortality after trauma and sepsis is mainly based on experimental data indicating that sex hormones have relevant effects on various organs and the immune system after trauma and sepsis [38]. In general, 17- $\beta$-estradiol (E2) and estrogen-receptor agonists were shown to have beneficial effects on organ function, tissue damage (e.g., neutrophil infiltration, edema formation) and the immune response, whereas androgens (e.g., testosterone) were associated with enhanced organ damage and a dysfunctional immune system [39-42]. For example, E2 was shown to be beneficial for cardiac function after trauma-hemorrhage (TH) (e.g., increased cardiac output) due to protective effects on myocardial mitochondria, induction of heme oxygenase-1 (HO-1) [43], downregulation of nuclear factor kappa-light-chain-enhancer of activated B-cells (NF- $k$ B) and the modulation of inflammatory mediators, such as heat shock proteins (HSP) and cytokines. In this context, E2 decreased the likelihood of cardiomyocyte necrosis by increasing HSP70 levels [44]. Furthermore, an E2-associated reduction of pulmonary damage after TH with a decrease of edema and neutrophil infiltration was observed $[45,46]$. As potential mechanisms for the beneficial hepatic effects of E2, a restoration of liver metabolism (normalization of adenosine triphosphate) and a reduction of apoptosis by up-regulation of Bcl-2 and induction of HO-1, heat shock proteins (HSP) and p38 mitogen activated protein kinase (p38 MAPK) was discussed. E2 attenuated acute renal injury by reducing apoptosis, endothelial cell damage and inflammation. Moreover, the intestine benefits from posttraumatic E2-application due to an increased blood flow and a decrease of neutrophil infiltration $[45,47,48]$. Furthermore, sex hormones significantly modulated cellular and humoral immune functions after TH. Interestingly, enzymes relevant for the synthesis of sex steroids were also found in immune cells (e.g., T-cells). The expression and activity of these enzymes were modulated by $\mathrm{TH}$ and differed between males and proestrus females. In males, TH resulted in increased levels of $5 \alpha$-reductase which catalyzes the synthesis of $5 \alpha$-dihydrotestosterone ( $5 \alpha$-DHT). $5 \alpha$-DHT itself is well known to exert even more pronounced immunosuppressive effects than testosterone. In contrast, in proestrus females, an enhanced aromatase activity was observed which resulted in an increased E2 synthesis [49]. Thus, these changes might contribute to the gender-related differences found after TH and sepsis [40]. Focusing on specific immune cells, macrophages from different tissue compartments were shown to respond differently following TH with an increased productive capacity for TNF- $\alpha$ and IL-6 of hepatic (Kupffer cells) and alveolar macrophages and a decreased synthesis of splenic and peritoneal macrophages [40]. Administration of E2 resulted in a normalization of the productive capacity but also in a beneficial modulation of toll-like receptor (TLR) and iNOS synthesis [48]. Furthermore, both dendritic (reduced antigen presentation) and T-cell function (shift from T-helper (Th) 1 to Th2-cell) were impaired after $\mathrm{TH}$, which was assumed to contribute to the increased susceptibility for infectious complications after trauma. Again, these changes were especially pronounced in males and were reversed by E2-treatment [50,51]. In addition, an E2-induced interference with the apoptosis rate of immune cells and the synthesis of HSP was verified [2,39,51].

It has been proven that these effects of sex hormones are mediated by specific androgen- (AR) and estrogen (ER) receptors, which are expressed by almost all cells. For AR no further major subdivision is reported, whereas ER are subdivided in two major subtypes, ER $\alpha$ - and ER- $\beta$. The distribution of these ER is organ specific. In both, lung and heart, the effects of E2 seem to be mediated via ER- $\beta$ [52]. In the liver, ER- $\alpha$ dependent effects were primarily described; however, ER- $\alpha$-independent effects were also found [53]. Moreover, in the intestine, ER $\alpha$ - and ER- $\beta$ mediated effects of E2 were found [54]. Hepatic 
and splenic macrophages and T-cells seem to preferably express ER- $\alpha$ and show improved function after administration of E2 or the selective ER- $\alpha$-agonist propyl pyrazole triol (PPT) [42], whereas alveolar macrophages normalized posttraumatic function after application of a ER- $\beta$-agonist [40]. Based on the aforementioned results, it seems likely that ER subtypes may have tissue-specific roles in mediating the effects of E2 after TH.

All these aforementioned, beneficial effects on the various organs and the immune system might contribute to the improved survival observed after E2-application in animal models of TH even without large volume fluid resuscitation. In these studies, an E2-associated shift of the remaining blood into heart, liver and kidney has been discussed as a further favorable aspect [55-57].

Although sex hormones have been described to also influence human immune cell function, knowledge about these effects after $\mathrm{TH}$ and sepsis is relatively sparse. After infections, human mononuclear cells from males were shown to produce lower levels of type I interferons (IFN) in response to TLR-7 ligands and higher IL-10 in response to TLR-9 ligands as compared to females [58]. Furthermore, women were shown to have an enhanced capability of producing antibodies $[59,60]$. Clinical studies also described effects on the humoral immune response after multiple trauma and sepsis $[61,62]$. In this context, females younger than 50 years with an ISS $>25$ had significantly lower plasma cytokines after multiple trauma [62].

Furthermore, diverse clinical studies found evidence for a more favorable clinical course after trauma and sepsis for females. In this context, female gender was associated with a lower incidence of posttraumatic infections (e.g., pneumonia, sepsis) and multiple organ failure (MOF) [63-68]. As a result, less requirements for intensive care were associated in female patients [69].

In some studies, however, only premenopausal females (in most studies defined as $<50$ years) showed lower incidences of posttraumatic complications (e.g., sepsis, MOF, mortality), a reduction of lactate levels and decreased blood transfusion requirements compared to males of the same age $[62,65,66,70-73]$. This might support the findings of the aforementioned experimental studies indicating a beneficial effect of E2 on the further clinical course. However, both, reduced sepsis rates and survival benefits have also been described for postmenopausal women $[61,74,75]$. Here, persistently increased androgen levels and the associated immunosuppression in males might play a role.

In the search for the mechanisms of the immunomodulating effect of estrogen, myeloid-derived suppressor cells (MDSC), a heterogeneous population of the myeloid lineage, which modulate the adaptive immune response, have attracted the focus of research efforts [76]. These cell subtypes have been shown to constitute a crucial component of the innate immune system in various inflammatory states. During systemic inflammation, MDSCs are recruited from the bone marrow [77]. In this respect, it could be shown in different mouse models that after CLP procedure and recruitment, an accumulation of MDSCs takes place in secondary lymphatic organs. The recruitment of MDSCs is mediated by MAMPs (e.g., LPS) and DAMPs (e.g., HMGB1) [77-79]. Furthermore, MDSC are induced and activated in the presence of estrogen and cytokines, such as IL- 6 , IFN- $\gamma$ and IL- $1 \beta$, and strongly contribute to T-cell dysfunction in various diseases such as sepsis, tumorigenesis and trauma [80-82]. Especially in the case of estrogen, a direct activation of the STAT3 signaling pathway and upregulation of JAK2 and SRC in MDSCs and a consecutive anti-inflammatory function of MDSCs could be demonstrated [83].

However, results on sex-related differences after trauma and sepsis are not unequivocal. Some studies found no differences for complications (e.g., sepsis) and mortality after blunt trauma $[62,67,70,84,85]$, whereas even increased mortality rates for females with an age around 80 years were observed by Eachempati et al. [86]. Without specifically considering patient's age, also others described an increased mortality rate in females after development of infections (e.g., pneumonia, sepsis) or after major surgery [86,87]. In a study of Dossett et al. increasing levels of E2 were even associated to a higher mortality rate of critically ill patients [88].

There might be different reasons for these partly divergent results. Despite significant effects of the estrous cycle on E2 levels, none of the aforementioned studies has determined the cycle phase, 
some did not consider age. In addition, the effects of co-morbidities, pre-medication (e.g., oral contraceptives, hormone replacement therapy), injury severity and distribution (e.g., traumatic brain injury, TBI) have not been considered so far. In this context, it is well known that TBI has the potential to depress systemic E2 levels; however, this association has not been taken into account in most of the studies [89]. Consideration of patients with mild or moderate trauma and a low risk of adverse outcome might keep gender-related effects from becoming visible [65]. In this regard, diverse studies found gender-associated divergences only in patients with a high overall injury severity $[62,73,90]$.

In conclusion, particularly based on experimental but also indirectly from clinical studies $[62,65]$, it is likely that not the gender itself, but sex hormones influence the immune response, the incidence of complications and the outcome after trauma and sepsis $[9,89]$. Therefore, consideration of the sex hormone status could be an important step for an individual therapeutic approach after trauma. Therapeutic utilization of the interaction of E2/testosterone with the immune system after trauma and sepsis may offer new strategies. These include the application of E2, ER-agonists, androgen receptor antagonists and $\alpha$-reductase-inhibitors, which prevent the conversion of testosterone into highly active dihydrotestosterone. However, up until now, no clinical trials have been published investigating the clinical value of these approaches (Table 1).

\section{Dehydroepiandrosterone (DHEA)}

DHEA, the most abundant circulating steroid in humans is mainly synthesized in the adrenal cortex. It has been well described to be involved in the response to trauma and sepsis [91]. Beside trauma- and sepsis-related effects on DHEA-synthesis and -metabolism, an immunomodulatory potency of DHEA under the aforementioned conditions has been proven in experimental studies. In this context, a beneficial effect of DHEA on the incidence of complications, the clinical status, survival and immune function after hemorrhagic shock, infections and a combination of these insults has been described $[13,92,93]$. Furthermore, an improved function of the cellular immune system, which includes a marked improvement of the proliferation rate of lymphocytes with a simultaneous decrease of the apoptosis rate of lymphocytes, was observed. At the same time, a varied pattern of cytokine release with a DHEA-induced inhibition of TNF- $\alpha$, IL- 6 and IL-10 release was found $[13,92]$. Accordingly, administration of DHEA immediately before induction of TH normalized immune cell migration (NK-cells, CD4+ and CD8+ lymphocytes) and splenocyte apoptosis rate in a murine model of hemorrhagic shock [94]. In a murine model of bilateral femoral fractures DHEA suppressed the serum levels of proinflammatory cytokines (IL-6, TNF- $\alpha$, MCP-1) and also of IL-10 but did not improve markers of pulmonary inflammation [95]. Same effects of DHEA were found in case of neuroinflammation after TBI. In addition, DHEA resulted in improved long-term cognitive and behavioral outcome [96]. DHEA-treatment after infections displayed an increased survival rate, reduced bacterial contamination in the peritoneal fluid, decreased pro-inflammatory (e.g., TNF- $\alpha$, IL-6) and enhanced anti-inflammatory cytokine release (e.g., IL-4, IL-10). These DHEA-associated changes of the inflammatory response were supposed to be caused by suppressed NO-secretion and a shift towards the Th2 response. Furthermore, an improved delayed-type of hypersensitivity reaction after DHEA-application was observed, demonstrating that apart from the innate immune system, also a modulation of the acquired part of the immune system is initiated [97,98]. In contrast, administration of DHEA in a murine sepsis model of cecal ligation and puncture revealed that there was no difference in the survival rate, the cellular proliferation and apoptosis rate whether mice received DHEA immediately before induction of a polymicrobial sepsis or after the development of the first septic symptoms [97]. The way of DHEA administration might represent a potential reason for these different findings. In this context, it was shown that subcutaneous administration of DHEA was accompanied by an improved survival and normalized immune functions whereas intravenous or intraperitoneal treatment with DHEA failed to exert the expected effects on the survival rate and immune functions of septic mice. Moreover, a varyingly strong activation of the HSP-70 release in the 
different shock organs (lunge, liver, kidney) could be detected in septic mice dependent on the way of DHEA administration [99].

However, it is of major relevance to note that transfer of animal data to the human situation has to be interpreted with caution. In this context, rodent adrenal DHEA production is modest compared to that of humans. Furthermore, these animals have the ability to convert exogenous DHEA to sex steroids. Therefore, studies specifically focusing on the human situation are of upmost importance. However, in vitro and clinical studies on the effects of DHEA on immune cells after trauma and sepsis are rare. In an in vitro study, DHEA-S was able to stimulate the synthesis of reactive oxygen species (ROS) via NADPH oxidase activation directly and thereby improve neutrophil function [100]. Neutrophils hold a unique position among the leukocytes, since they are the only subpopulation with an active transporter, the organic anion-transporting polypeptide D (OATP-D). Furthermore, neutrophils do not have steroid sulfatase, which activates DHEAS to DHEA. The effect of DHEA consequently must be a direct one. In addition, in case of primary adrenal insufficiency with a frequently associated deficit of DHEA/DHEAS, an impaired natural killer cell cytotoxic function was found. However, this impaired function was not influenced by longstanding DHEA-therapy [101]. Apart from this direct influence of DHEA on immune cells, an intracellular metabolization into sex steroids was postulated. In this respect, DHEA related activation of monocytes and their interaction with endothelial cells was shown to depend on the conversion to androgens and subsequent binding on androgen receptors [102]. DHEA may also antagonize the effects of glucocorticoids but also act as an inhibitor of the glucose-6-phosphatase in the hyperglycemic environments that are common after trauma [103]. Additionally, it was shown that cells of the immune system are able to synthesize DHEA, which could influence the cell function in an autocrine control loop [13].

In this context, it could be shown that the GR receptor is also expressed on circulating MDSCs. Lu et al. could show in an experimental study on a liver injury mouse model that the modulating effect of glucocorticoids is caused by suppression/activation of HIF1 $\alpha$ and HIF1 $\alpha$-dependent glycolysis [104]. Based on these observations, the modulation of MDSC function by systemic steroids may represent a new therapeutic target, although detailed data on the timing of use and type of steroid are still lacking. Furthermore, the function of MDSC in sepsis and trauma has not been sufficiently studied $[105,106]$. The vast majority of data are based on studies in tumors, although an increasing number of studies highlight the role of MDSC subtypes in the resolution of inflammation after severe sepsis and trauma $[106,107]$.

In the clinical setting, DHEA and DHEAS serum levels have been shown to immediately decrease in multiple trauma patients, indicating an early trauma-related reduction of adrenal androgen synthesis $[11,20]$. In the further clinical course, a stepwise recovery towards pre-traumatic levels over a period of several months was described. Interestingly, this recovery was significantly influenced by the medication over the clinical course, e.g., with a relevant delay in case of opioid treatment [11]. The decline of DHEAS was both, more pronounced and permanent compared to DHEA, suggesting an additional downregulation of DHEA sulfation after trauma [11,108]. As particularly low levels of DHEAS have been associated with an impaired immune function and higher complications rates (e.g., infections, mortality) [11,109], substitution of DHEAS or DHEA with stimulation of its sulfation might represent promising approaches for a beneficial modulation of the posttraumatic course. This is also true for septic patients who also demonstrated a significant reduction of DHEAS levels [108].

Cortisol and DHEAS appear to be the antagonists. DHEAS has the potential to counteract the immunosuppressive effect of cortisol. In post-traumatic and septic conditions, a decrease in DHEAS has been shown to enhance the immunosuppressive effect of cortisol [110].

Under additional consideration of the positive modulatory influence of DHEA on the immune system without proven significant adverse effects in experimental studies, a clinical utilization of DHEA or DHEA-S within the framework of controlled test conditions, for example, in septic or trauma patients, would be a possible step to prove the efficiency of this new therapeutic approach. However, interventional clinical studies so far only exist for healthy volunteers and patients with autoimmune 
disorders or osteoporosis who showed beneficial effects on immune response or the underlying disease (e.g., reduced inflammatory response, increased bone mass) $[12,13]$. For practicality of DHEA supplementation in case of trauma or sepsis, specific considerations in terms of dosing, delivery and safety under specific posttraumatic or -infectious conditions (e.g., polypharmacy, impaired hepatic function) are obligatory needed (Table 1).

\section{Sympathetic-Adrenergic (SAS) and Parasympathetic-Cholinergic (PCS) System}

The immunomodulatory effect of the activation of the sympatho-adrenergic system (SAS) by catecholamines has been known for a long time and has been proven by several animal and human studies. Likewise, the expression of $\alpha$ - as well as $\beta$-adrenergic receptors, those in a higher density, on the surface of nearly all cells of the immune system could be validated [111]. The subcutaneous or intravenous administration of the catecholamines adrenalin and noradrenalin leads to marked changes of the migration behavior and activity of circulating T- and NK-cells in healthy volunteers. This effect was inhibited by the administration of a non-selective but not of a $\beta 1$-selective antagonist, which indicates that the effect might be mediated by $\beta 2$-receptors [112]. Even after release of endogenous catecholamines, similar effects could be found [111]. Furthermore, it could be shown that catecholamines influence the release of pro- (IL-1 $\beta$, IL-2, IL-6, IL-12, TNF- $\alpha$ ) as well as anti-inflammatory cytokines (IL-10), and these effects could also be inhibited by the administration of $\beta$-adrenergic antagonists. Considering a synopsis of current literature, concerning TH1-cytokines, a rather inhibiting impact could be observed whereas with the release of TH2-cytokines, an activating impact seems to predominate [111,113]. Overall, catecholamines in vitro inhibit the adaptive immunity by reducing the proliferation of $\mathrm{T}$ helper, $\mathrm{T}$ cytotoxic and B-cells and shifting the TH1/TH2 balance towards Th2 cells [114]. In this context, it should be mentioned that the catecholamine dopamine is a potent inhibitor of the MDSC-mediated immunosuppression via the DA and D1-like receptors [115]. MDSCs have been shown to play a central role in the regulation of the pro-inflammation response in the early stage of sepsis. Their function seems to be the limitation of hyperinflammation by L-arginine degradation, production of ROS and NO, the secretion of anti-inflammatory cytokines like IL-10, inducing apoptosis mediated by FAS-FASL, and the activation of T regulatory cells (Tregs) [116-119]. On the other hand, this anti-inflammatory role seems to be disadvantageous in the later course of sepsis [120]. A function of MDSCs that has been insufficiently investigated so far involves the cell-cell crosstalk with macrophages, the induction of an M2 phenotype and the associated influence of MDSCs on the resolution of inflammation [121]. In the context of a consecutive chronic critical illness and a persistent inflammation immunosuppression and catabolism syndrome, MDSCs appear to be essential for the preservation of existing immunosuppression by suppression of the lymphocyte proliferation [120].

It was shown that adrenaline and noradrenaline are able to influence the release of pro- and anti-inflammatory cytokines, and it was postulated that both catecholamines are involved in the dysregulation of the immune system [111]. Accordingly, an animal model of hemorrhagic shock showed that the shock-induced mobilization of immune cells is blocked independently of the blood pressure by pharmacological blocking of adrenergic $\beta$-receptors. Additionally, an increased apoptosis rate of splenocytes was documented [122]. In another study using a murine sepsis model, the pharmacological blocking of adrenergic $\beta$-receptors led to an inhibition of the proliferation as well as an increased apoptosis rate of splenocytes and a varied release of cytokines (IFN- $\gamma$, IL-6). These immunological effects were accompanied by an increased mortality rate and a deteriorated clinical situation of the mice [123]. Similar results have been shown after selective inhibition of $\beta 2$-receptors in a mouse sepsis model $[122,124]$. The exogenous infusion of adrenaline led to significant changes of the distribution of immune cells in the blood of septic mice. The apoptosis and proliferation rate of splenocytes and the release of cytokines were also significantly different without effects on the mortality rate or clinical situation. Additional administration of propranolol intensified the adrenergic effects on the apoptosis of immune cells, antagonized the adrenalin-induced cell mobilization and led to an increased release of IL-6. These effects were accompanied by a markedly increased mortality. Further studies 
about the pharmacological blocking of adrenergic $\beta$-receptors in animal models of sepsis prove a modulation of the release of pro- and anti-inflammatory cytokines even though the results are partially controversial [124].

The impact of circulating catecholamines or the blocking of adrenergic receptors on the immune system could also be shown under conditions of hemorrhagic shock and sepsis. Most of these data are based on animal studies, but in a small prospective study in trauma patients, it could be shown that administration of $\beta$-receptor blockers decreased serum IL-6 levels and that patients pretreated with $\beta$-receptor blockers had lower initial base deficits after trauma [125]. Clinical studies concerning the immunomodulatory effects of catecholamines in multiple-injured or septic patients are rare, because the use of hypotensive drugs, such as $\beta$-blockers in severe sepsis and septic shock, raises justified safety issues. Beyond that, the administration of catecholamines or of $\beta$-adrenergic antagonists is often clinically without alternative. A retrospective study reported that critically ill trauma patients receiving $\beta$-blockers had a significantly lower in-hospital mortality compared to patients with similar ISS scores not receiving $\beta$-blockers (11\% vs. 19\%) [126]. In general, $\beta$-blockers are used in sepsis under the intention to modulate the cardiovascular system but not to influence the inflammatory response; nonetheless $\beta$-blockade resulted in a decreased 28 day mortality in septic patients treated with esmolol [127]. Critically ill septic patients with chronic $\beta$-blocker prescriptions had lower 28 day mortality than sensitivity and pair-matched controls [128]. These improved outcomes with $\beta$-blockers could be due to decreased myocardial oxygen demand [129], improved myocardial oxygen utilization [130] and/or immunomodulation of hypercatecholaminemia [131].

Although several beneficial effects of $\beta$-blockers in trauma and sepsis have been described, including restoration of normal cellular metabolism, improved glucose regulation and improved cardiac function [132], the consequences of this interaction for the clinical treatment of patients after multiple trauma or during sepsis in terms of immunomodulation are not clear. The effects of $\beta$-blockade on infectious outcomes following the systemic inflammatory response syndrome (SIRS) [133] and the compensatory anti-inflammatory response syndrome (CARS) [134] are unknown. Therefore, more basic research is needed to elucidate the intra- and extracellular mechanisms of immunomodulation of $\beta$-blockers. Further, it has to be determined which patients may benefit and especially at which timepoint in the treatment course since an initial sympathetic activation after injury is beneficial but a persistent severe overactivation detrimental. Therefore, the immune suppressive side effects of the $\beta$-adrenergic antagonists should be critically included in the therapy decision.

Besides the sympathetic-adrenergic system, also the parasympathetic-cholinergic system (PCS) is able to modulate the inflammatory response $[135,136]$. The activation of the parasympathetic-cholinergic system via the release of the neurotransmitter acetylcholine (ACh) results in an immune-suppression by inhibition of cytokine production [137]. ACh binds to both nicotinic and muscarinic cholinergic receptors. The main nicotinic cholinergic receptor found on macrophages is the $\alpha 7$ nicotinic $\mathrm{ACh}$ receptor subunit $(\alpha 7 \mathrm{nAChR})$ [137]. It is believed that cholinergic agonists through the activation of $\alpha 7 \mathrm{nACh}$ receptors inhibit NF- $\mathrm{KB}$ activation and hence downregulate the production of pro- inflammatory cytokines, such as TNF $\alpha$ [137]. Cholinergic stimulation has been shown to reduce pro- inflammatory cytokine production and prevent lethal tissue injury in multiple models of local and systemic inflammation and sepsis, including acute lung injury, hemorrhagic shock or polymicrobial sepsis [136]. These findings encouraged researchers to assess the therapeutic potential of vagus nerve stimulation (VNS) in attenuating the systemic inflammatory responses evoked by endotoxemia [137]. Direct electrical stimulation of the peripheral vagus nerve in vivo during lethal endotoxemia in rats inhibited TNF $\alpha$ synthesis in the liver, attenuated peak serum TNF $\alpha$ amounts and prevented the development of shock [137]. A beneficial effect of VNS immunomodulation has been reported in other studies for different immunological pathologies [137]. Interestingly, the immunomodulatory effect of vagus nerve stimulation in terms of systemic TNF $\alpha$ reduction is dependent on the spleen, since it fails to work in splenectomized animals [136]. Interruption of the common celiac branch of the abdominal 
vagus nerve abolishes vagal anti-inflammatory effects, suggesting that cholinergic signaling targets the spleen via this specific branch of the vagus nerve [136].

To date, there are no human studies reporting on the specific pharmacological stimulation of the parasympathetic-cholinergic system in order to modulate the inflammatory response in trauma or septic patients. Nonetheless, transcutaneous mechanical vagus nerve stimulation can exhibit anti-inflammatory effects that may be considered in the clinical setting under special circumstances (Table 1).

\section{Conclusions}

With the exception of corticosteroids, up-to-date proactive modulation of the inflammatory response following trauma and sepsis has not been introduced into clinical practice. Although animal studies show great potential of neuroendocrine immune modulation following trauma and sepsis, knowledge concerning dosage and timing in clinical practice remains unclear. Especially the potential of severe side-effects caused by modulation of this highly complex and dynamic inflammatory response cannot be predicted so far. Future studies are required to achieve the transfer of promising data from bench to bedside.

Author Contributions: Conceptualization, P.K. and F.H.; resources, F.H.; writing-original draft preparation, P.K. and F.H.; writing - review and editing, F.M.B., P.L., R.O. and F.H.; supervision, F.H. All authors have read and agreed to the published version of the manuscript.

Funding: This research received no external funding.

Conflicts of Interest: The authors declare no conflict of interest.

\section{References}

1. Nast-Kolb, D.; Aufmkolk, M.; Rucholtz, S.; Obertacke, U.; Waydhas, C. Multiple organ failure still a major cause of morbidity but not mortality in blunt multiple trauma. J. Trauma 2001, 51, 835-841. [CrossRef] [PubMed]

2. Neunaber, C.; Zeckey, C.; Andruszkow, H.; Frink, M.; Mommsen, P.; Krettek, C.; Hildebrand, F. Immunomodulation in polytrauma and polymicrobial sepsis-Where do we stand? Recent Pat. Inflamm. Allergy Drug Discov. 2011, 5, 17-25. [CrossRef] [PubMed]

3. Hildebrand, F.P.H.K.C. Die Bedeutung der Zytokine in der posttraumatischen Entzündungsreaktion. Unfallchirurg 2005, 108, 793-803. [CrossRef] [PubMed]

4. Kirchhoff, C.; Biberthaler, P.; Mutschler, W.E.; Faist, E.; Jochum, M.; Zedler, S. Early down-regulation of the pro-inflammatory potential of monocytes is correlated to organ dysfunction in patients after severe multiple injury: A cohort study. Crit. Care 2009, 13, R88. [CrossRef]

5. Gann, D.S.; Lilly, M.P. The neuroendocrine response to multiple trauma. World J. Surg. 1983, 7, 101-118. [CrossRef]

6. Kumar, V.; Sharma, A. Is neuroimmunomodulation a future therapeutic approach for sepsis? Int. Immunopharmacol. 2010, 10, 9-17. [CrossRef]

7. Madden, K.S.; Sanders, V.M.; Felten, D.L. Catecholamine influences and sympathetic neural modulation of immune responsiveness. Annu. Rev. Pharmacol. Toxicol. 1995, 35, 417-448. [CrossRef]

8. Vermes, I.; Beishuizen, A. The hypothalamic-pituitary-adrenal response to critical illness. Best Pract. Res. Clin. Endocrinol. Metab. 2001, 15, 495-511. [CrossRef]

9. Bösch, F.; Angele, M.K.; Chaudry, I.H. Gender differences in trauma, shock and sepsis. Mil. Med. Res. 2018, 5, 35. [CrossRef]

10. Beishuizen, A.; Thijs, L.G.; Vermes, I. Decreased levels of dehydroepiandrosterone sulphate in severe critical illness: A sign of exhausted adrenal reserve? Crit. Care 2002, 6, 434-438. [CrossRef]

11. Foster,M.A.; Taylor, A.E.; Hill,N.E.; Bentley, C.; Bishop, J.; Gilligan, L.C.; Shaheen, F.; Bion, J.F.; Fallowfield, J.L.; Woods, D.R.; et al. Mapping the steroid response to major trauma from injury to recovery: A prospective cohort study. J. Clin. Endocrinol. Metab. 2020, 105, 925-937. [CrossRef] [PubMed] 
12. Williams, J.R. The effects of dehydroepiandrosterone on carcinogenesis, obesity, the immune system, and aging. Lipids 2000, 35, 325-331. [CrossRef]

13. Oberbeck, R.; Kobbe, P. Dehydroepiandrosterone (DHEA): A steroid with multiple effects. Is there any possible option in the treatment of critical illness? Curr. Med. Chem. 2010, 17, 1039-1047. [CrossRef] [PubMed]

14. Dhatariya, K.K. Is there a role for dehydroepiandrosterone replacement in the intensive care population? Intensive Care Med. 2003, 29, 1877-1880. [CrossRef] [PubMed]

15. Marx, C.; Petros, S.; Bornstein, S.R.; Weise, M.; Wendt, M.; Menschikowski, M.; Engelmann, L.; Höffken, G. Adrenocortical hormones in survivors and nonsurvivors of severe sepsis: Diverse time course of dehydroepiandrosterone, dehydroepiandrosterone-sulfate, and cortisol. Crit. Care Med. 2003, 31, 1382-1388. [CrossRef]

16. Marik, P.E. Glucocorticoids in sepsis: Dissecting facts from fiction. Crit. Care 2011, 15, 158. [CrossRef]

17. Elenkov, I.J. Glucocorticoids and the Th1/Th2 balance. Ann. N. Y. Acad. Sci. 2004, 1024, 138-146. [CrossRef]

18. Ronchetti, S.; Ricci, E.; Migliorati, G.; Gentili, M.; Riccardi, C. How glucocorticoids affect the neutrophil life. Int. J. Mol. Sci. 2018, 19, 4090. [CrossRef]

19. Joyce, D.A.; Steer, J.H.; Abraham, L.J. Glucocorticoid modulation of human monocyte/macrophage function: Control of TNF- $\alpha$ secretion. Inflamm. Res. 1997, 46, 447-451. [CrossRef]

20. Brorsson, C.; Dahlqvist, P.; Nilsson, L.; Thunberg, J.; Sylvan, A.; Naredi, S. Adrenal response after trauma is affected by time after trauma and sedative/analgesic drugs. Injury 2014, 45, 1149-1155. [CrossRef]

21. Thieringer, R.; Le Grand, C.B.; Carbin, L.; Cai, T.Q.; Wong, B.; Wright, S.D.; Hermanowski-Vosatka, A. 11 Beta-hydroxysteroid dehydrogenase type 1 is induced in human monocytes upon differentiation to macrophages. J. Immunol. 2001, 167, 30-35. [CrossRef] [PubMed]

22. Chapman, K.; Holmes, M.; Seckl, J. 11ß-hydroxysteroid dehydrogenases: Intracellular gate-keepers of tissue glucocorticoid action. Physiol. Rev. 2013, 93, 1139-1206. [CrossRef] [PubMed]

23. Chapman, K.E.; Coutinho, A.E.; Zhang, Z.; Kipari, T.; Savill, J.S.; Seckl, J.R. Changing glucocorticoid action: $11 \beta$-hydroxysteroid dehydrogenase type 1 in acute and chronic inflammation. J. Steroid. Biochem. Mol. Biol. 2013, 137, 82-92. [CrossRef] [PubMed]

24. Wang, P.; Ba, Z.F.; Jarrar, D.; Cioffi, W.G.; Bland, K.I.; Chaudry, I.H. Mechanism of adrenal insufficiency following trauma and severe hemorrhage: Role of hepatic 11beta-hydroxysteroid dehydrogenase. Arch. Surg. 1999, 134, 394-401. [CrossRef]

25. Annane, D. The role of acth and corticosteroids for sepsis and septic shock: An update. Front. Endocrinol. 2016, 7, 70. [CrossRef]

26. Sprung, C.L.; Annane, D.; Keh, D.; Moreno, R.; Singer, M.; Freivogel, K.; Weiss, Y.G.; Benbenishty, J.; Kalenka, A.; Forst, H.; et al. Hydrocortisone therapy for patients with septic shock. N. Engl. J. Med. 2008, 358, 111-124. [CrossRef]

27. Rhodes, A.; Chiche, J.D.; Moreno, R. Improving the quality of training programs in intensive care: A view from the ESICM. Intensive Care Med. 2011, 37, 377-379. [CrossRef]

28. Roquilly, A.; Mahe, P.J.; Seguin, P.; Guitton, C.; Floch, H.; Tellier, A.C.; Merson, L.; Renard, B.; Malledant, Y.; Flet, L.; et al. Hydrocortisone therapy for patients with multiple trauma: The randomized controlled HYPOLYTE study. JAMA 2011, 305, 1201-1209. [CrossRef]

29. Vardas, K.; Ilia, S.; Sertedaki, A.; Charmandari, E.; Briassouli, E.; Goukos, D.; Apostolou, K.; Psarra, K.; Botoula, E.; Tsagarakis, S.; et al. Increased glucocorticoid receptor expression in sepsis is related to heat shock proteins, cytokines, and cortisol and is associated with increased mortality. Intensive Care Med. Exp. 2017, 5, 10. [CrossRef]

30. Butler, E.; Møller, M.H.; Cook, O.; Granholm, A.; Penketh, J.; Rygård, S.L.; Aneman, A.; Perner, A. The effect of systemic corticosteroids on the incidence of gastrointestinal bleeding in critically ill adults: A systematic review with meta-analysis. Intensive Care Med. 2019, 45, 1540-1549. [CrossRef]

31. Lian, X.J.; Huang, D.Z.; Cao, Y.S.; Wei, Y.X.; Lian, Z.Z.; Qin, T.H.; He, P.C.; Liu, Y.H.; Wang, S.H. Reevaluating the role of corticosteroids in septic shock: An updated meta-analysis of randomized controlled trials. Biomed. Res. Int. 2019, 2019, 3175047. [CrossRef] [PubMed]

32. Fang, F.; Zhang, Y.; Tang, J.; Lunsford, L.D.; Li, T.; Tang, R.; He, J.; Xu, P.; Faramand, A.; Xu, J.; et al. Association of corticosteroid treatment with outcomes in adult patients with sepsis: A systematic review and meta-analysis. JAMA Intern. Med. 2019, 179, 213-223. [CrossRef] 
33. Annane, D.; Bellissant, E.; Bollaert, P.E.; Briegel, J.; Confalonieri, M.; De Gaudio, R.; Keh, D.; Kupfer, Y.; Oppert, M.; Meduri, G.U. Corticosteroids in the treatment of severe sepsis and septic shock in adults: A systematic review. JAMA 2009, 301, 2362-2375. [CrossRef]

34. Oberbeck, R.; Schmitz, D.; Wilsenack, K.; Schüler, M.; Biskup, C.; Schedlowski, M.; Nast-Kolb, D.; Exton, M.S. Prolactin modulates survival and cellular immune functions in septic mice. J. Surg. Res. 2003, 113, 248-256. [CrossRef]

35. Schleimer, R.P. An overview of glucocorticoid anti-inflammatory actions. Eur. J. Clin. Pharmacol. 1993, 45 (Suppl. 1), S3-S7. [CrossRef] [PubMed]

36. McCann, S.M.; Kimura, M.; Karanth, S.; Yu, W.H.; Mastronardi, C.A.; Rettori, V. The mechanism of action of cytokines to control the release of hypothalamic and pituitary hormones in infection. Ann. N. Y. Acad. Sci. 2000, 917, 4-18. [CrossRef]

37. Bulger, E.M.; Jurkovich, G.J.; Farver, C.L.; Klotz, P.; Maier, R.V. Oxandrolone does not improve outcome of ventilator dependent surgical patients. Ann. Surg. 2004, 240, 472-478. [CrossRef]

38. Angele, M.K.; Schwacha, M.G.; Ayala, A.; Chaudry, I.H. Effect of gender and sex hormones on immune responses following shock. Shock 2000, 14, 81-90. [CrossRef]

39. Bird, M.D.; Karavitis, J.; Kovacs, E.J. Sex differences and estrogen modulation of the cellular immune response after injury. Cell. Immunol. 2008, 252, 57-67. [CrossRef]

40. Choudhry, M.A.; Bland, K.I.; Chaudry, I.H. Trauma and immune response-Effect of gender differences. Injury 2007, 38, 1382-1391. [CrossRef]

41. Sperry, J.L.; Minei, J.P. Gender dimorphism following injury: Making the connection from bench to bedside. J. Leukoc. Biol. 2008, 83, 499-506. [CrossRef] [PubMed]

42. Weniger, M.; Angele, M.K.; Chaudry, I.H. The role and use of estrogens following trauma. Shock 2016, 46 (Suppl. 1), 4-11. [CrossRef] [PubMed]

43. Szalay, L.; Shimizu, T.; Schwacha, M.G.; Choudhry, M.A.; Loring WRue, I.; Bland, K.I.; Chaudry, I.H. Mechanism of salutary effects of estradiol on organ function after trauma-hemorrhage: Upregulation of heme oxygenase. Am. J. Physiol. Heart Circ. Physiol. 2005, 289, H92-H98. [CrossRef]

44. Voss, M.R.; Stallone, J.N.; Li, M.; Cornelussen, R.N.; Knuefermann, P.; Knowlton, A.A. Gender differences in the expression of heat shock proteins: The effect of estrogen. Am. J. Physiol. Heart. Circ. Physiol. 2003, 285, H687-H692. [CrossRef] [PubMed]

45. Kawasaki, T.; Chaudry, I.H. The effects of estrogen on various organs: Therapeutic approach for sepsis, trauma, and reperfusion injury. Part 2: Liver, intestine, spleen, and kidney. J. Anesth. 2012, 26, 892-899. [CrossRef] [PubMed]

46. Frink, M.; Thobe, B.M.; Hsieh, Y.C.; Choudhry, M.A.; Schwacha, M.G.; Bland, K.I.; Chaudry, I.H. 17 $\beta$-Estradiol inhibits keratinocyte-derived chemokine production following trauma-hemorrhage. Am. J. Physiol. Lung Cell. Mol. Physiol. 2007, 292, L585-L591. [CrossRef] [PubMed]

47. Yu, H.P.; Pang, S.T.; Chaudry, I.H. Hepatic gene expression patterns following trauma-hemorrhage: Effect of posttreatment with estrogen. Shock 2013, 39, 77-82. [CrossRef] [PubMed]

48. Yu, H.P.; Hsieh, Y.C.; Suzuki, T.; Choudhry, M.A.; Schwacha, M.G.; Bland, K.I.; Chaudry, I.H. Mechanism of the nongenomic effects of estrogen on intestinal myeloperoxidase activity following trauma-hemorrhage: Up-regulation of the PI-3K/Akt pathway. J. Leukoc. Biol. 2007, 82, 774-780. [CrossRef]

49. Samy, T.S.A.; Zheng, R.; Matsutani, T.; Loring, W.; Rue, I.; Bland, K.I.; Chaudry, I.H. Mechanism for normal splenic T lymphocyte functions in proestrus females after trauma: Enhanced local synthesis of $17 \beta$-estradiol. Am. J. Physiol.Cell Physiol. 2003, 285, C139-C149. [CrossRef]

50. Angele, M.K.; Knöferl, M.W.; Ayala, A.; Bland, K.I.; Chaudry, I.H. Testosterone and estrogen differently effect Th1 and Th2 cytokine release following trauma-haemorrhage. Cytokine 2001, 16, 22-30. [CrossRef]

51. Choudhry, M.A.; Schwacha, M.G.; Hubbard, W.J.; Kerby, J.D.; Rue, L.W.; Bland, K.I.; Chaudry, I.H. Gender differences in acute response to trauma-hemorrhage. Shock 2005, 24 (Suppl. 1), 101-106. [CrossRef]

52. Yu, H.P.; Hsieh, Y.C.; Suzuki, T.; Shimizu, T.; Choudhry, M.A.; Schwacha, M.G.; Chaudry, I.H. Salutary effects of estrogen receptor-beta agonist on lung injury after trauma-hemorrhage. Am. J. Physiol. Lung Cell. Mol. Physiol. 2006, 290, L1004-L1009. [CrossRef] [PubMed]

53. Hsieh, Y.C.; Yu, H.P.; Frink, M.; Suzuki, T.; Choudhry, M.A.; Schwacha, M.G.; Chaudry, I.H. G protein-coupled receptor 30-dependent protein kinase A pathway is critical in nongenomic effects of estrogen in attenuating liver injury after trauma-hemorrhage. Am. J. Pathol. 2007, 170, 1210-1218. [CrossRef] 
54. Yu, H.P.; Shimizu, T.; Hsieh, Y.C.; Suzuki, T.; Choudhry, M.A.; Schwacha, M.G.; Chaudry, I.H. Tissue-specific expression of estrogen receptors and their role in the regulation of neutrophil infiltration in various organs following trauma-hemorrhage. J. Leukoc. Biol. 2006, 79, 963-970. [CrossRef] [PubMed]

55. Hubbard, W.; Keith, J.; Berman, J.; Miller, M.; Scott, C.; Peck, C.; Chaudry, I.H. $17 \alpha$-Ethynylestradiol-3-sulfate treatment of severe blood loss in rats. J. Surg. Res. 2015, 193, 355-360. [CrossRef] [PubMed]

56. Kim, H.; Chen, J.; Zinn, K.R.; Hubbard, W.J.; Fineberg, N.S.; Chaudry, I.H. Single photon emission computed tomography demonstrated efficacy of $17 \beta$-estradiol therapy in male rats after trauma-hemorrhage and extended hypotension. J. Trauma 2010, 69, 1266-1273. [CrossRef]

57. Miller, M.; Keith, J.; Berman, J.; Burlington, D.B.; Grudzinskas, C.; Hubbard, W.; Peck, C.; Scott, C.; Chaudry, I.H. Efficacy of $17 \alpha$-ethynylestradiol-3-sulfate for severe hemorrhage in minipigs in the absence of fluid resuscitation. J. Trauma Acute Care Surg. 2014, 76, 1409-1416. [CrossRef]

58. Tayel, S.S.; Helmy, A.A.; Ahmed, R.; Esmat, G.; Hamdi, N.; Abdelaziz, A.I. Progesterone suppresses interferon signaling by repressing TLR-7 and MxA expression in peripheral blood mononuclear cells of patients infected with hepatitis C virus. Arch. Virol. 2013, 158, 1755-1764. [CrossRef]

59. Bouman, A.; Heineman, M.J.; Faas, M.M. Sex hormones and the immune response in humans. Hum. Reprod. Update 2005, 11, 411-423. [CrossRef]

60. Taneja, V. Sex hormones determine immune response. Front. Immunol. 2018, 9, 1931. [CrossRef]

61. Schröder, J.; Kahlke, V.; Staubach, K.H.; Zabel, P.; Stüber, F. Gender differences in human sepsis. Arch. Surg. 1998, 133, 1200-1205. [CrossRef]

62. Frink, M.; Pape, H.C.; van Griensven, M.; Krettek, C.; Chaudry, I.H.; Hildebrand, F. Influence of sex and age on mods and cytokines after multiple injuries. Shock 2007, 27, 151-156. [CrossRef] [PubMed]

63. Offner, P.J.; Moore, E.E.; Biffl, W.L. Male gender is a risk factor for major infections after surgery. Arch. Surg. 1999, 134, 935-938. [CrossRef] [PubMed]

64. Gannon, C.J.; Pasquale, M.; Tracy, J.K.; McCarter, R.J.; Napolitano, L.M. Male gender is associated with increased risk for postinjury pneumonia. Shock 2004, 21, 410-414. [CrossRef] [PubMed]

65. Trentzsch, H.; Lefering, R.; Nienaber, U.; Kraft, R.; Faist, E.; Piltz, S. The role of biological sex in severely traumatized patients on outcomes: A matched-pair analysis. Ann. Surg. 2015, 261, 774-780. [CrossRef] [PubMed]

66. Trentzsch, H.; Nienaber, U.; Behnke, M.; Lefering, R.; Piltz, S. Female sex protects from organ failure and sepsis after major trauma haemorrhage. Injury 2014, 45 (Suppl. 3), S20-S28. [CrossRef] [PubMed]

67. Schoeneberg, C.; Kauther, M.D.; Hussmann, B.; Keitel, J.; Schmitz, D.; Lendemans, S. Gender-specific differences in severely injured patients between 2002 and 2011: Data analysis with matched-pair analysis. Crit. Care 2013, 17, R277. [CrossRef]

68. Wichmann, M.W.; Müller, C.; Meyer, G.; Adam, M.; Angele, M.K.; Eisenmenger, S.J.; Schildberg, F.W. Different immune responses to abdominal surgery in men and women. Langenbecks Arch. Surg. 2003, 387, 397-401. [CrossRef]

69. Wichmann, M.W.; Inthorn, D.; Andress, H.J.; Schildberg, F.W. Incidence and mortality of severe sepsis in surgical intensive care patients: The influence of patient gender on disease process and outcome. Intensive Care Med. 2000, 26, 167-172. [CrossRef] [PubMed]

70. Mostafa, G.; Huynh, T.; Sing, R.F.; Miles, W.S.; Norton, H.J.; Thomason, M.H. Gender-related outcomes in trauma. J. Trauma 2002, 53, 430-434. [CrossRef]

71. Deitch, E.A.; Livingston, D.H.; Lavery, R.F.; Monaghan, S.F.; Bongu, A.; Machiedo, G.W. Hormonally active women tolerate shock-trauma better than do men: A prospective study of over 4000 trauma patients. Ann. Surg. 2007, 246, 447-453. [CrossRef] [PubMed]

72. Haider, A.H.; Crompton, J.G.; Chang, D.C.; Efron, D.T.; Haut, E.R.; Handly, N.; Cornwell, E.E., 3rd. Evidence of hormonal basis for improved survival among females with trauma-associated shock: An analysis of the National Trauma Data Bank. J. Trauma 2010, 69, 537-540. [CrossRef] [PubMed]

73. Wohltmann, C.D.; Franklin, G.A.; Boaz, P.W.; Luchette, F.A.; Kearney, P.A.; Richardson, J.D.; Spain, D.A. A multicenter evaluation of whether gender dimorphism affects survival after trauma. Am. J. Surg. 2001, 181, 297-300. [CrossRef]

74. Oberholzer, A.; Keel, M.; Zellweger, R.; Steckholzer, U.; Trentz, O.; Ertel, W. Incidence of septic complications and multiple organ failure in severely injured patients is sex specific. J. Trauma 2000, 48, 932-937. [CrossRef] 
75. George, R.L.; McGwin, G.; Jr Metzger, J.; Chaudry, I.H.; Rue, L.W., 3rd. The association between gender and mortality among trauma patients as modified by age. J. Trauma 2003, 54, 464-471. [CrossRef]

76. Hüsecken, Y.; Muche, S.; Kustermann, M.; Klingspor, M.; Palmer, A.; Braumüller, S.; Huber-Lang, M.; Debatin, K.-M.; Strauss, G. MDSCs are induced after experimental blunt chest trauma and subsequently alter antigen-specific T cell responses. Sci. Rep. 2017, 7, 12808. [CrossRef]

77. Ray, A.; Chakraborty, K.; Ray, P. Immunosuppressive MDSCs induced by TLR signaling during infection and role in resolution of inflammation. Front. Cell. Infect. Microbiol. 2013, 3, 52. [CrossRef]

78. Bayik, D.; Tross, D.; Klinman, D.M. Factors influencing the differentiation of human monocytic myeloid-derived suppressor cells into inflammatory macrophages. Front. Immunol. 2018, 9, 608. [CrossRef]

79. Greifenberg, V.; Ribechini, E.; Rössner, S.; Lutz, M.B. Myeloid-derived suppressor cell activation by combined LPS and IFN-gamma treatment impairs DC development. Eur. J. Immunol. 2009, 39, 2865-2876. [CrossRef]

80. Condamine, T.; Gabrilovich, D.I. Molecular mechanisms regulating myeloid-derived suppressor cell differentiation and function. Trends Immunol. 2011, 32, 19-25. [CrossRef]

81. Uhel, F.; Azzaoui, I.; Grégoire, M.; Pangault, C.; Dulong, J.; Tadié, J.M.; Gacouin, A.; Camus, C.; Cynober, L.; Fest, T.; et al. Early expansion of circulating granulocytic myeloid-derived suppressor cells predicts development of nosocomial infections in patients with sepsis. Am. J. Respir. Crit. Care Med. 2017, 196, 315-327. [CrossRef] [PubMed]

82. Cuenca, A.G.; Delano, M.J.; Kelly-Scumpia, K.M.; Moreno, C.; Scumpia, P.O.; Laface, D.M.; Heyworth, P.G.; Efron, P.A.; Moldawer, L.L. A paradoxical role for myeloid-derived suppressor cells in sepsis and trauma. Mol. Med. 2011, 17, 281-292. [CrossRef]

83. Svoronos, N.; Perales-Puchalt, A.; Allegrezza, M.J.; Rutkowski, M.R.; Payne, K.K.; Tesone, A.J.; Nguyen, J.M.; Curiel, T.J.; Cadungog, M.G.; Singhal, S.; et al. Tumor cell-independent estrogen signaling drives disease progression through mobilization of myeloid-derived suppressor cells. Cancer Discov. 2017, 7, 72-85. [CrossRef] [PubMed]

84. Rappold, J.F.; Coimbra, R.; Hoyt, D.B.; Potenza, B.M.; Fortlage, D.; Holbrook, T.; Minard, G. Female gender does not protect blunt trauma patients from complications and mortality. J. Trauma 2002, 53, $436-441$. [CrossRef]

85. Gannon, C.J.; Napolitano, L.M.; Pasquale, M.; Tracy, J.K.; McCarter, R.J. A statewide population-based study of gender differences in trauma: Validation of a prior single-institution study. J. Am. Coll. Surg. 2002, 195, 11-18. [CrossRef]

86. Eachempati, S.R.; Hydo, L.; Barie, P.S. Gender-based differences in outcome in patients with sepsis. Arch. Surg. 1999, 134, 1342-1347. [CrossRef] [PubMed]

87. Napolitano, L.M.; Greco, M.E.; Rodriguez, A.; Kufera, J.A.; West, R.S.; Scalea, T.M. Gender differences in adverse outcomes after blunt trauma. J. Trauma 2001, 50, 274-280. [CrossRef] [PubMed]

88. Dossett, L.A.; Swenson, B.R.; Heffernan, D.; Bonatti, H.; Metzger, R.; Sawyer, R.G.; May, A.K. High levels of endogenous estrogens are associated with death in the critically injured adult. J. Trauma 2008, 64, 580-585. [CrossRef]

89. Weniger, M.; D'Haese, J.G.; Angele, M.K.; Chaudry, I.H. Potential therapeutic targets for sepsis in women. Exp. Opin. Ther. Targets 2015, 19, 1531-1543. [CrossRef]

90. Magnotti, L.J.; Fischer, P.E.; Zarzaur, B.L.; Fabian, T.C.; Croce, M.A. Impact of gender on outcomes after blunt injury: A definitive analysis of more than 36,000 trauma patients. J. Am. Coll. Surg. 2008, 206, 984-991. [CrossRef]

91. Bentley, C.; Hazeldine, J.; Greig, C.; Lord, J.; Foster, M. Dehydroepiandrosterone: A potential therapeutic agent in the treatment and rehabilitation of the traumatically injured patient. Burns Trauma 2019, 7, 26. [CrossRef] [PubMed]

92. Hildebrand, F.; Pape, H.-C.; Hoevel, P.; Krettek, C.; van Griensven, M. The importance of systemic cytokines in the pathogenesis of polymicrobial sepsis and dehydroepiandrosterone treatment in a rodent model. Shock 2003, 20, 338-346. [CrossRef] [PubMed]

93. Barkhausen, T.; Hildebrand, F.; Krettek, C.; van Griensven, M. DHEA-dependent and organ-specific regulation of TNF-alpha mRNA expression in a murine polymicrobial sepsis and trauma model. Crit. Care 2009, 13, R114. [CrossRef] [PubMed] 
94. Oberbeck, R.; Nickel, E.; von Griensven, M.; Tschernig, T.; Wittwer, T.; Schmitz, D.; Pape, H.C. The effect of dehydroepiandrosterone on hemorrhage-induced suppression of cellular immune function. Intensive Care Med. 2002, 28, 963-968. [CrossRef]

95. Lichte, P.; Pfeifer, R.; Werner, B.E.; Ewers, P.; Tohidnezhad, M.; Pufe, T.; Hildebrand, F.; Pape, H.C.; Kobbe, P. Dehydroepiandrosterone modulates the inflammatory response in a bilateral femoral shaft fracture model. Eur. J. Med. Res. 2014, 19, 27. [CrossRef] [PubMed]

96. Yilmaz, C.; Karali, K.; Fodelianaki, G.; Gravanis, A.; Chavakis, T.; Charalampopoulos, I.; Alexaki, V.I. Neurosteroids as regulators of neuroinflammation. Front. Neuroendocrinol. 2019, 55, 100788. [CrossRef] [PubMed]

97. Schmitz, D.; Kobbe, P.; Wegner, A.; Hammes, F.; Oberbeck, R. Dehydroepiandrosterone during sepsis: Does the timing of administration influence the effectiveness. J. Surg. Res. 2010, 163, e73-e77. [CrossRef]

98. Zhao, J.; Cao, J.; Yu, L.; Ma, H. Dehydroepiandrosterone resisted E. Coli O157:H7-induced inflammation via blocking the activation of p38 MAPK and NF-кB pathways in mice. Cytokine 2020, 127, 154955. [CrossRef]

99. Oberbeck, R.; Deckert, H.; Bangen, J.; Kobbe, P.; Schmitz, D. Dehydroepiandrosterone: A modulator of cellular immunity and heat shock protein 70 production during polymicrobial sepsis. Intensive Care Med. 2007, 33, 2207-2213. [CrossRef]

100. Radford, D.J.; Wang, K.; McNelis, J.C.; Taylor, A.E.; Hechenberger, G.; Hofmann, J.; Chahal, H.; Arlt, W.; Lord, J.M. Dehydroepiandrosterone sulfate directly activates protein kinase C- $\beta$ to increase human neutrophil superoxide generation. Mol. Endocrinol. 2010, 24, 813-821. [CrossRef]

101. Bancos, I.; Hazeldine, J.; Chortis, V.; Hampson, P.; Taylor, A.E.; Lord, J.M.; Arlt, W. Primary adrenal insufficiency is associated with impaired natural killer cell function: A potential link to increased mortality. Eur. J. Endocrinol. 2017, 176, 471-480. [CrossRef] [PubMed]

102. Corsini, E.; Galbiati, V.; Papale, A.; Kummer, E.; Pinto, A.; Serafini, M.M.; Guaita, A.; Spezzano, R.; Caruso, D.; Marinovich, M.; et al. Role of androgens in dhea-induced rack1 expression and cytokine modulation in monocytes. Immunity Ageing I A 2016, 13, 20. [CrossRef] [PubMed]

103. Perner, A.; Nielsen, S.E.; Rask-Madsen, J. High glucose impairs superoxide production from isolated blood neutrophils. Intensive Care Med. 2003, 29, 642-645. [CrossRef]

104. Lu, Y.; Liu, H.; Bi, Y.; Yang, H.; Li, Y.; Wang, J.; Zhang, Z.; Wang, Y.; Li, C.; Jia, A.; et al. Glucocorticoid receptor promotes the function of myeloid-derived suppressor cells by suppressing HIF1 $\alpha$-dependent glycolysis. Cell. Mol. Immunol. 2018, 15, 618-629. [CrossRef]

105. Jiang, J.K.; Fang, W.; Hong, L.J.; Lu, Y.Q. Distribution and differentiation of myeloid-derived suppressor cells after fluid resuscitation in mice with hemorrhagic shock. J. Zhejiang Univ. Sci. B 2017, 18, 48-58. [CrossRef] [PubMed]

106. Cheng, L.; Xu, J.; Chai, Y.; Wang, C.; Han, P. Dynamic changes in trauma-induced myeloid-derived suppressor cells after polytrauma are associated with an increased susceptibility to infection. Int. J. Clin. Exp. Pathol. 2017, 10, 11063-11068.

107. Schrijver, I.T.; Théroude, C.; Roger, T. Myeloid-derived suppressor cells in sepsis. Front. Immunol. 2019, 10, 327. [CrossRef] [PubMed]

108. Arlt, W.; Hammer, F.; Sanning, P.; Butcher, S.K.; Lord, J.M.; Allolio, B.; Annane, D.; Stewart, P.M. Dissociation of serum dehydroepiandrosterone and dehydroepiandrosterone sulfate in septic shock. J. Clin. Endocrinol. Metab. 2006, 91, 2548-2554. [CrossRef]

109. Butcher, S.K.; Killampalli, V.; Lascelles, D.; Wang, K.; Alpar, E.K.; Lord, J.M. Raised cortisol:DHEAS ratios in the elderly after injury: Potential impact upon neutrophil function and immunity. Aging Cell 2005, 4, 319-324. [CrossRef]

110. De Castro, R.; Ruiz, D.; Lavín, B.A.; Lamsfus, J.; Vázquez, L.; Montalban, C.; Marcano, G.; Sarabia, R.; Paz-Zulueta, M.; Blanco, C.; et al. Cortisol and adrenal androgens as independent predictors of mortality in septic patients. PLoS ONE 2019, 14, e0214312. [CrossRef]

111. Oberbeck, R. Catecholamines: Physiological immunomodulators during health and illness. Curr. Med. Chem. 2006, 13, 1979-1989. [CrossRef] [PubMed]

112. Schedlowski, M.; Hosch, W.; Oberbeck, R.; Benschop, R.J.; Jacobs, R.; Raab, H.R.; Schmidt, R.E. Catecholamines modulate human NK cell circulation and function via spleen-independent beta 2-adrenergic mechanisms. J. Immunol. 1996, 156, 93-99. [PubMed] 
113. Molina, P.E. Neurobiology of the stress response: Contribution of the sympathetic nervous system to the neuroimmune axis in traumatic injury. Shock 2005, 24, 3-10. [CrossRef] [PubMed]

114. Andreis, D.T.; Singer, M. Catecholamines for inflammatory shock: A Jekyll-and-Hyde conundrum. Intensive Care Med. 2016, 42, 1387-1397. [CrossRef] [PubMed]

115. Wu, J.; Zhang, R.; Tang, N.; Gong, Z.; Zhou, J.; Chen, Y.; Chen, K.; Cai, W. Dopamine inhibits the function of Gr-1+CD115+ myeloid-derived suppressor cells through D1-like receptors and enhances anti-tumor immunity. J. Leukoc. Biol. 2015, 97, 191-200. [CrossRef]

116. Wijnands, K.A.; Meesters, D.M.; van Barneveld, K.W.; Visschers, R.G.; Briedé, J.J.; Vandendriessche, B.; van Eijk, H.M.; Bessems, B.A.; van den Hoven, N.; von Wintersdorff, C.J.; et al. Citrulline supplementation improves organ perfusion and arginine availability under conditions with enhanced arginase activity. Nutrients 2015, 7, 5217-5238. [CrossRef]

117. Köstlin, N.; Vogelmann, M.; Spring, B.; Schwarz, J.; Feucht, J.; Härtel, C.; Orlikowsky, T.W.; Poets, C.F.; Gille, C. Granulocytic myeloid-derived suppressor cells from human cord blood modulate T-helper cell response towards an anti-inflammatory phenotype. Immunology 2017, 152, 89-101. [CrossRef]

118. Gabrilovich, D.I.; Nagaraj, S. Myeloid-derived suppressor cells as regulators of the immune system. Nat. Rev. Immunol. 2009, 9, 162-174. [CrossRef]

119. Sinha, P.; Chornoguz, O.; Clements, V.K.; Artemenko, K.A.; Zubarev, R.A.; Ostrand-Rosenberg, S. Myeloid-derived suppressor cells express the death receptor Fas and apoptose in response to T cell-expressed FasL. Blood 2011, 117, 5381-5390. [CrossRef]

120. Venet, F.; Monneret, G. Advances in the understanding and treatment of sepsis-induced immunosuppression. Nat. Rev. Nephrol. 2018, 14, 121-137. [CrossRef]

121. Ostrand-Rosenberg, S. Myeloid-derived suppressor cells: More mechanisms for inhibiting antitumor immunity. Cancer Immunol. Immunother. 2010, 59, 1593-1600. [CrossRef] [PubMed]

122. Oberbeck, R.; Kobbe, P. Beta-adrenergic antagonists: Indications and potential immunomodulatory side effects in the critically ill. Curr. Med. Chem. 2009, 16, 1082-1090. [CrossRef] [PubMed]

123. Schmitz, D.; Wilsenack, K.; Lendemanns, S.; Schedlowski, M.; Oberbeck, R. Beta-Adrenergic blockade during systemic inflammation: Impact on cellular immune functions and survival in a murine model of sepsis. Resuscitation 2007, 72, 286-294. [CrossRef] [PubMed]

124. Oberbeck, R.; Schmitz, D.; Schüler, M.; Wilsenack, K.; Schedlowski, M.; Exton, M. Dopexamine and cellular immune functions during systemic inflammation. Immunobiology 2004, 208, 429-438. [CrossRef]

125. Friese, R.S.; Barber, R.; McBride, D.; Bender, J.; Gentilello, L.M. Could Beta blockade improve outcome after injury by modulating inflammatory profiles? J. Trauma 2008, 64, 1061-1068. [CrossRef]

126. Bukur, M.; Lustenberger, T.; Cotton, B.; Arbabi, S.; Talving, P.; Salim, A.; Ley, E.J.; Inaba, K. Beta-blocker exposure in the absence of significant head injuries is associated with reduced mortality in critically ill patients. Am. J. Surg. 2012, 204, 697-703. [CrossRef]

127. Morelli, A.; Ertmer, C.; Westphal, M.; Rehberg, S.; Kampmeier, T.; Ligges, S.; Orecchioni, A.; D’Egidio, A.; D'Ippoliti, F.; Raffone, C.; et al. Effect of heart rate control with esmolol on hemodynamic and clinical outcomes in patients with septic shock: A randomized clinical trial. JAMA 2013, 310, 1683-1691. [CrossRef]

128. Macchia, A.; Romero, M.; Comignani, P.D.; Mariani, J.; D’Ettorre, A.; Prini, N.; Santopinto, M.; Tognoni, G. Previous prescription of $\beta$-blockers is associated with reduced mortality among patients hospitalized in intensive care units for sepsis. Crit. Care Med. 2012, 40, 2768-2772. [CrossRef]

129. Taniguchi, T.; Kurita, A.; Yamamoto, K.; Inaba, H. Effects of carvedilol on mortality and inflammatory responses to severe hemorrhagic shock in rats. Shock 2009, 32, 272-275. [CrossRef]

130. Huang, L.; Weil, M.H.; Cammarata, G.; Sun, S.; Tang, W. Nonselective beta-blocking agent improves the outcome of cardiopulmonary resuscitation in a rat model. Crit. Care Med. 2004, 32 (Suppl. 9), S378-S380. [CrossRef]

131. Oberbeck, R.; van Griensven, M.; Nickel, E.; Tschernig, T.; Wittwer, T.; Pape, H.-C. Influence of beta-adrenoceptor antagonists on hemorrhage-induced cellular immune suppression. Shock 2002, 18, 331-335. [CrossRef] [PubMed]

132. Feinman, R.; Deitch, E.A.; Aris, V.; Chu, H.B.; Abungu, B.; Caputo, F.J.; Galante, A.; Xu, D.; Lu, Q.; Colorado, I.; et al. Molecular signatures of trauma-hemorrhagic shock-induced lung injury: Hemorrhageand injury-associated genes. Shock 2007, 28, 360-368. [CrossRef] [PubMed] 
133. Davies, M.G.; Hagen, P.O. Systemic inflammatory response syndrome. Br. J. Surg. 1997, 84, 920-935. [CrossRef]

134. Bone, R.C. Sir Isaac Newton, sepsis, SIRS, and CARS. Crit. Care Med. 1996, 24, 1125-1128. [CrossRef] [PubMed]

135. Pavlov, V.A.; Wang, H.; Czura, C.J.; Friedman, S.G.; Tracey, K.J. The cholinergic anti-inflammatory pathway: A missing link in neuroimmunomodulation. Mol. Med. 2003, 9, 125-134. [CrossRef] [PubMed]

136. Huston, J.M. The vagus nerve and the inflammatory reflex: Wandering on a new treatment paradigm for systemic inflammation and sepsis. Surg. Infect. 2012, 13, 187-193. [CrossRef]

137. Jarczyk, J.; Yard, B.A.; Hoeger, S. The cholinergic anti-inflammatory pathway as a conceptual framework to treat inflammation-mediated renal injury. Kidney Blood Press. Res. 2019, 44, 435-448. [CrossRef]

C 2020 by the authors. Licensee MDPI, Basel, Switzerland. This article is an open access article distributed under the terms and conditions of the Creative Commons Attribution (CC BY) license (http://creativecommons.org/licenses/by/4.0/). 